\title{
半導体の歴史
}

\section{古川吉 孝*}

\section{1.はじめに}

新材料が時代を一変させることは鉄器の出現と いった古い話しを引用するまでもなく，少なくと も戦前を知っている人にとっては，日常生活に深 く入りこんだプラスチックあるいは半導体を思い だすだけで十分であろう。

ゲルマニウムに 2 本の金属針を立てた点接触形 トランジスタで増幅作用が見いだされてから，今 日寸でに 40 年を経過した。 シリコン IC は今や産 業の米と呼ばれるほど広く一般に使用されてい る.この夏, トランジスタの発明者の一人である Shockleyの訃報に接して, あらためて時の流れ を感じさせられる.この時期に一度半導体材料の 歴史をごく簡単にふりかえってみたい。

半導体の発見は新しく，たかだか150年前のこ とである。それはその特異な性質, すなわち整流 性, 光伝導性によってであり, したがって発見当 初から電気応用と結びついていた。ここでは半導 体素子としては構造が最も簡単で, しかも無線通 信の進歩に決定的な役割を演じたダイオード(検 波器, ミキサ)の变遷を通して半導体を眺めるこ ととしたい。なお直流電源用の半導体整流器につ いても, 半導体の発見がそもとも整流性にあった ことを考慮して若干言及することとした。

\section{2. 第二次大戦前}

金属とある種の鉱石, 化合物との接触が非対称 な電気伝導を示すことを最初に観測したのは Munck(1835年)であるが(1), Braunが On the conduction of current through sulpometals といら 論文を1871年(明治 7 年)に発表したことに始まる とする人も多い(2). 同じ1874年に Schuster は錆

* 東北大学教授; 工学部材料物性学科

History of Semiconductors; Yoshitaka Furukawa

(Faculty of Engineering, Tohoku University, Sendai)

Keywords: semiconductors, point contact diode, Schottky barrier, crystal growth, history

1989 年 10 月 20 日受理
びた銅と銅の接触が整流性を示すことを見いだし ている。ちなみに，現在 IC に広く使用されてい るシリコンが元素として分離されたのは1823年の ことであり，ゲルマニウムの分離は1886年のこと である，話しは変るが，Hertzは針金の輪の先に つけた金属球間に火花が飛ぶことで1888年初めて 電波の検出に成功した.

Marconi はこの電波を通信に応用した，当初彼 が用いた検波器はコヒラ(coherer) と呼ばれるも のであった。これは Branly が 1890 年に発明した もので，金属電極間に小量の金属粉を置き，ガラ ス管に真空封入したものである. Marconi は銀電 極間に銀粉とニッケル粉を混合したものを用い た。コヒラに電波が到来すると金属粉は絶縁状態 から電気抵抗の低い状態に遷移する(逆の場合も ある). 当時に扎いても, 金属粉の表面酸化膜が この現象に関与していることは, 金粉のような酸 化しにくい金属粉ではコヒラ作用が得られないこ とから見当がついていた。しかしながらそれ以上 のことはわからないままにデバイスとしての生命 を終えた。

たとえば1915年(大正 4 年)に出版された鳥潟の 無線電信電話という本 ${ }^{(3)}$ には, コヒラについて, 銅之鋼との接触面に電波が働く時には電気抵抗が 低減し, 鉛と酸化鉛との接触の場合には抵抗が増 大することが述べられている。そしてコヒラの原 理は不明であり，いわゆる電子論によって初めて 真相が得られるものであろらが，原子，電子の観 念はまだ十分完全でないと述べている，さらに検 波器については数十百種あるがすべてその原理は 不明であること, 検波器は無線にとって極めて重 要であり, かつ研究上もっとも興味あるものであ ると書いている。ちなみに電気試験所の技師であ った彼は鉱石検波器の研究で勲五等双光旭日章の 叙勲を受けた。

コヒラは現代の MIM (metal-insulator-metal) に 対応すると思われるが，insulator を半導体と拡大 解釈してここで取り上げた。コヒラの実物は横須 賀に保存されている戦艦三笠の無線室で見ること ができる(図 1)。これは第二高等学校教授であっ 


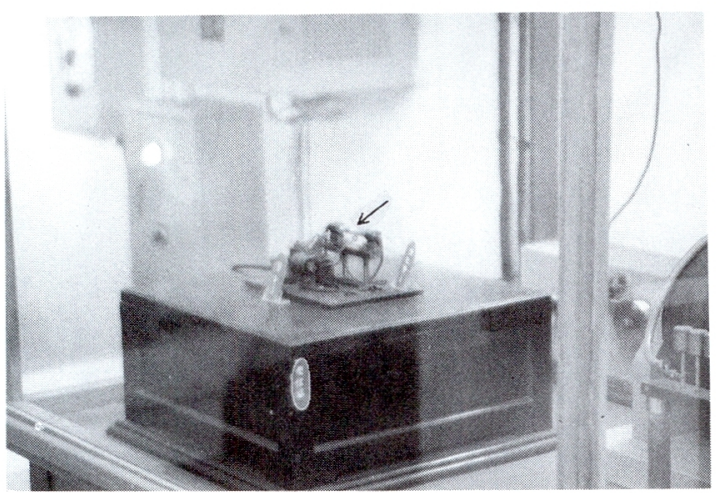

図1コヒラ(矢印の部分がコヒラ本体).

た木村駿吉の研究になるものである.

図 2 (a)のような鉱石検波器が無線で使用され るようになったのは日露戦争後のことである。最 初はカーボランダムを真鍮に圧接したものであ り，後供黄銅鉱と紅严鉛鉱との組合せが用いられ た。 Pickardは1906年この鉱石検波器に改良を加 え, cat wisker と呼ばれる細い金属針を鉱石に接 触させた。彼がこの時すでにシリコンを使用して いることは大変興味深い。しかし実際に広く利用 されたのはガレナ検波器であって，方鉛鉱に針を 立てたものであった。

この鉱石検波器もコヒラ同様その動作原理はわ からない束実用に供されていた。前述の鳥潟の 本には，同じ結晶表面でも針を立てる場所ごとに 感度が異なっており，これはその物質の特殊な性 質と言うより他なく，動作原理に至っては全く不 明と書かれている。半導体に金属を接触させた時 に生じる整流性は今日 Schottky barrier によるも のであると理解されているが，それは1929年に量 子力学が確立し, 固体への応用が始交ってから後 のことである。
無線の初期に使用された鉱石検波器はやがて二 極真空管にとって代られる，真空中で熱電子放射 が起きることをEdison は1883年に観測している が，無線受信用二極真空管を最初に製作したのは Fleming (1903年)である。その後，三極真空管に よる信号の増幅が可能になり，真空管の時代が到 来する。それは大正末期のことであり，ラジオの 普及をもたらした。

ところで直流電源用の整流器について眺めると,

Pickard が cat wisker を発明したのと同じ年に Pawlowski は硫化第一銅整流器を作っている。こ の整流器は整流作用が不安定なため実用にならな かった、その後, Grondahlにより銅表面を酸化 した覀酸化銅整流器が実用化された。チリ産の銅 でないと良い特性が得られないなどと言われた。

硫化物, 酸化物之ともにセレンならびにセレン 化物についても整流性が古くから知られていたが, Presser は1923年にセレン整流器の特許を得た。 初期のものは亜酸化銅整流器より劣っていたが, 1933年に吹き付け形になってから亜酸化銅整流器 にとって代るよらになった。それはニッケルメッ キした鉄板上にセレンを薄く溶着し，熱処理を行 なって半導体化した後，低融点金属を吹き付けた ものである。このセレン整流器は人ッキ，電気分 解用, あるいは電話局における電話電源用として 1960年代前半まで活躍した。

\section{3. 戦中戦後}

上述のように第二次大戦直前の無線は真空管の 時代であった，無線周波数が高い方へ高い方へと 伸びるにつれ真空管の高周波化が図られた。高周 波化に伴って電極間隔はせばまり，二極管ではど んぐりの実のような acorn 管が現われた，真空管 の応答速度は電子が陰極から陽極に到達するため

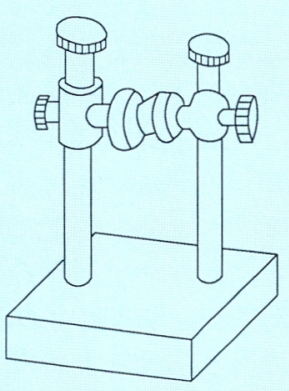

(a)

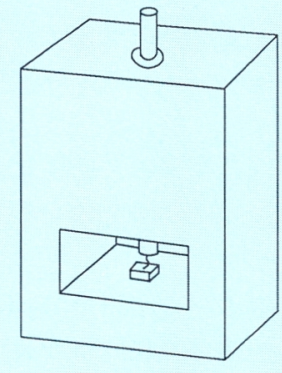

(b)

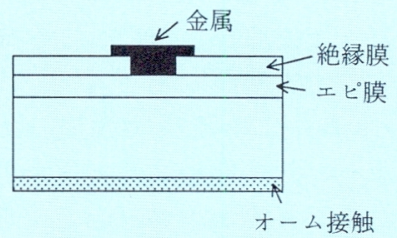

(c)

図 2 ダイオードの変遷.
(a)初期の鉱石検波器.
(b)ウエハ形ダイオード.
（c）ショットキバリヤダイオード。ダイオードは適当なケース に入れて使用する。 
に要する時間で制限される。したがって高い周波 数に応答するためには電極間距離をでさるだけ小 さくしなければならない。この事情は現代の IC でも同じであり, 周波数特性を上げるために, 素 子そのものを小さくすることは勿論, 素子と素子 をつなぐ配線の長さも短くしなければならないの である．真空管では高周波化に限界があり，そこ で大戦中に再びシリコン，ゲルマニウムダイオー ドが登場した。

戦後米国における研究情報が少しずつはいるよ らになり，わが国においても研究が再開された。 大戦中米国で行なわれた結晶整流器の研究成果 は, 戦後 MIT の Radiation Laboratory Series の 1 つとして Torrey, Whitmer により Crystall Rec-

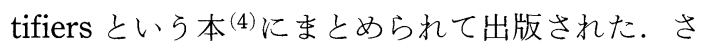
らにゲルマニウム点接触形トランジスタの発明の 報道は，その日の食糧に追われながらも多くの人 々の関心を集めた。

Crystal Rectifiers にはシリコンの精製，単結晶 成長，cat wiskerの製法などが記述されており， カートリッジ形のシリコンダイオード $1 \mathrm{~N} 23$ の写 真が掲載されている。戦後わが国に拈けるミキサ 用シリコンダイオードの開発については，その悪

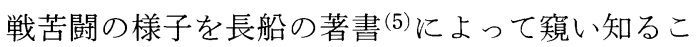
とができる。しかしながら当時はシリコンよりも むしろゲルマニウムの方に大方の関心が集まって いた.シリコンと比較すればゲルマニウムは希少 元素であり，原料はすべて輸入に頼らなければな らなかったが，精製，単結晶成長がシリコンにく らべ格段に容易であり，したがって従来の半導体 とくらべると実験データに再現性があったこと と，ゲルマニウムトランジスタに刺激されたこと によるものである.

当時輸入したゲルマニウムは Otavi 鉱山製の粉 末ゲルマニウムで，らっかりるつぼに蓋をしない で高周波加熱しようものなら， 汪とんど飛散して しまらといら代物であった。ゲルマニウム，シリ コンに対し， III族元素がアクセプタに，V族元素 がドナーに，そして $\mathrm{N}$ 族元素の錫，鉛は中性不純 物であることは今では半導体を習い始めるとすぐ に習らことであるが，このことが確立したのはい つ頃のことであったろらか？ 前述の Crystal Rectifiers の中にも不純物添加の記載があるが, 錫がドナーとして作用すると書かれている。錫の 中の微量の不純物がドナーとして作用したのであ る.

さきにも述べたよらにゲルマニウムは比較的取 扱いやすく，偏析を用いて純度を高めることもで きた。バケツの底に小さな孔をあげ，水をたらし
ながら水面に浮かんだフロートを少しずつ降下さ せ，このフロートに高周波コイルを連結してゆっ くりと移動させるといら方法で岩瀬らはゲルマニ ウムの偏析を行ない, 点接触形トランジスタをわ が国で初めて製作した．1950年(昭和25年)のこ とである。

ゲルマニウムの国産化と関連し，文部省により ゲルマニウム研究委員会が結成され, 多くの研究 機関の参加のもと研究が進められた。その成果は ゲルマニウムといら表題の本として出版された.

一方，わが国でシリコンの精製を最初に手がけた のは東北大学選鉱製鍊研究所の小野であった。そ れまでは，かますに入った純度 $98 \%$ かシリコンを 購入し，それを粉砕し，塩酸などで不純物を溶解 するといらもので, Crystal Rectifiers に書かれた 処方箋にしたがって行なった。今から考えるとど れ臣ど純度が上ったのか，全く疑わしい。

選鉱精鍊研究所でデュポン法により精製された シリコンは各所で研究に使用された。 日本電信電 話公社 (現 NTT) 電気通信研究所の所内資料を見 ると，1952年の金井の論文 “珪素及びゲルマニウ ムの電気的性質”にそのことが述べられている. すなわち，入手したシリコンをそのまま英国製透 明石英管に入れ $10^{-4} \mathrm{mmHg}\left(10^{-2} \mathrm{~Pa}\right)$ の真空中 でモリブデン炉で溶解したことが述べられてい る.

一方，東北大学工学部金属学科の金子ら ${ }^{(6)}$ は沃 化シリコンによるシリコン精製の研究を行なっ た。この方法は比較的低い温度で熱分解できるこ とに特長があった。この沃化物法は電々公社電気 通信研究所に和いても研究され，この研究との関 連で廃ガス処理機能を備えた特殊化学実験棟が建 てられた。このトーチカのよらな建物は今でも研 究所の一隅に残っている。沃化物法はその後メ一 カにより企業化が検討された．筆者は 2,3 回試 作シリコン原料による単結晶引上げを依頼され た.しかしながらシリコンはその後シラン法で作 られるよらになって今日に及んでいる。

チョクラルスキ法でシリコン単結晶の引上げが わが国でも可能になったのは1956年頃のことであ る.そしてその後10年の間にゲルマニウムは基礎 研究の分野からも汪とんど姿を消していった．現 在ではゲルマニウムは赤外レンズ等の光学素子に 使用される程度であるが, 昭和 20 年代に拈けるゲ ルマニウムは当時の人々にほとんど魔力的な響き をもって受け止められたのである。医薬品まがい の商品はすでにこの頃現われ，形を変えて今日に 及んでいる。

ところでダイオードの方はその後どのよらな展 
開があったかというと，ゲルマニウムに銀線を融 着したシルバボンドダイオード(喜田ダイオード) でパラメトリック作用が見いだされ注目を集め た. またミリ波領域に周波数が伸びるに伴い，力 ートリッジ形ではケースの容量がダイオードを高 周波的に短絡することになり，これを避けるため にダイオードを裸のまま導波管内に直接組込んだ ウエハ形ダイオードが現われた（図 $2(\mathrm{~b}))$ 。年れ は丁度わが国でシリコン単結晶引上げが始まった 頃である。またこの頃から欧米でIII- V 化合物半 導体に関する論文がぼつぼつ出はじめた。

\section{III- $V$ 化合物半導体}

III-V 化合物は 1910 年 (明治 43 年) Thiel が燐化 インジウムを発見したことに始まる. Huggins は この一群の化合物の結晶構造を1926年に発表して いる.この化合物が半導体であることを Blum は 1950年に発表したが， III-V化合物半導体といら とまずWelkerの名前が通常出てくる.それはこ の半導体の中のあるものが極めて高いキャリヤ移 動度を有していることを彼が最初に指摘したから であろう。この移動度はミキサ特性に大きな影響 を及ぼす因子であり，またシリコンMOSFETに 代る超高速トランジスタとして期待されている $\mathrm{GaAs}$ ショットキゲートFETはこの高移動度に 基礎を置いている.

砒化ガリウム $(\mathrm{GaAs})$ のバンド幅はシリコン, ゲルマニウムに比して大きく，かつ移動度も高い ことから，ダイオードの逆耐圧を傷ならことなく 直列抵抗を小さく寸ることができるので，ミリ波 帯ミキサ用半導体として好ましい特性をそなえて いる．従来の cat wisker の代りにホトリゾグラフ の技術を用いて，蒸着により微小な金属-半導体 接触を作ったのは Kahng(1964年)である(図 2 (c))。そしてダイオードの直列抵抗を下げるため に, 高不純物濃度の $\mathrm{GaAs}$ 基板上にェピタキシャ ル成長させた $\mathrm{GaAs}$ エピタキシャルウェハが用い られた。この $\mathrm{GaAs}$ ミキサは, わが国においても 地下埋設円形導波管によるミリ波通信の研究の一
環として研究された。

たしかに GaAs ミキサの実用化研究は $\mathrm{GaAs} の$ 材料研究を促進した。しかし加速の要因はむしろ 他にあった. GaAs pn 接合における高効率発光の 発見とそれに引続く pn 接合レーザの実現であり， Gunn ダイオードによるマイクロ波発振である. それはェピタキシャル技術の発展をらながし, 基 板としての大形 $\mathrm{GaAs}$ 単結晶引上げをらながし た. そして低損失光ファイバが出現し, 半導体レ 一ザの寿命に改善のきざしが見えると，導波管に よるミリ波通信の構想は消えていった.

しかしながら，前述の GaAs ミキサは現在衛星 通信の地上局に拈ける低雑音ミキサとして液体一 リウム温度で使用されている.ささらに金属-半導 体接触の金属として超伝導金属を用いたスーパー ショットキダイオードが McColl ら (1977年)によ って開発された.

以上, 金属-半導体接触のダイオードを通して 半導体のあゆみを概観した。 そこではシリコンが 意外に早い時機に顔を出していることに気づくで あろら。そして $1 \mathrm{~N} 23$ は今でも商品として健在で ある. 果して次にくるものは何であろらか？い ずれにしても早い時期に良い材料を見い出し，提 供することが材料屋にとって大切であることを歷 史は語っている。

な技，本文は東北大学工学部金属・材料系三学 科の学科公開における講演内容に若干補足したも のである.

\section{文献}

(1) A. Coblernz and H. Owens: Transistors, McGraw-Hill, (1955), 1.

（2）小谷銕治：金属整流器とその應用, オーム社, (1950), 3.

（3）鳥潟右一：無線電信電話, 宝文館, (1915).

(4) H. C. Torrey and C. A. Whitmer: Crystal Rectifiers, McGraw-Hill, (1948).

（5）長船廣衛: 半導体のあゆみ, 日本電気文化センター, (1987).

（6）金子秀夫, 増本 剛：日本金属学会誌，23，1(1959), 26. 